\title{
Relationship between Participation and Women Empowerment in the Tourism Industry; a Structural Equation Modeling Approach
}

Fadhila Hassan Abdalla ${ }^{1 *}$, Asnarulkhad Abuu Samah ${ }^{2}$, Ahmad Hariza Hashim ${ }^{3}$, Moh'd Roslan Rosnon ${ }^{4}$ Faculty of Human Ecology, University Putra Malaysia, Jalan Universiti 1 Serdang, 43400 Seri Kembangan, Selangor, Malaysia

*Corresponding Author: Fadhila Hassan Abdalla

Faculty of Human Ecology, University Putra Malaysia, Jalan Universiti 1 Serdang, 43400 Seri Kembangan, Selangor, Malaysia

\section{Article History}

Received: 18.12 .2021

Accepted: 01.02.2022

Published: 09.02.2022

\begin{abstract}
The Purpose: The purpose of this study is to examine the relationship on participation in decision making, implementation and benefit with women economic empowerment, psychological empowerment and social empowerment in tourism industry in Zanzibar. Design/methodology/approach: The study was survey, and multistage cluster sampling techniques were employed. The data was collected from 387 respondents using structured questionnaire from nine different wards of Zanzibar. The size and direction of the path coefficients was examined through PLS-SEM Algorithm and the significances of the relationship was examined through PLS-SEM bootstrapping procedure in the Smart-PLS 3.2. Findings: The results indicated that, there is direct relationship between participation in decision making with Economic Empowerment and Social Empowerment. Participation in benefit has significant relationship with Economic Empowerment and Psychological Empowerment. While participation in Implementation has no significant relationship with Economic Empowerment, psychological and social empowerment. Research limitations/implications: In theoretical perspective, the current study used only three dimensions among four dimensions developed from the Cohen and Uphoff participation theory and further tested on female gender only. Practical implication: The study contributes to the limited understanding on how women in Zanzibar community are reactive to various factors including standard of living, social wellbeing and self-confidence or self-employed. Originality/value: The quantitative consolidation of participation dimensions and examining their influence on women empowerment in tourism sector adds knowledge in the body of literature of community development as its rarely contested by the scholars.
\end{abstract}

Keywords: Community participation, women empowerment, tourism industry, participation in decision making, participation in implementation, participation in benefit, women economic empowerment, women social empowerment, women psychological empowerment.

\section{INTRODUCTION}

Participation and Women empowerment is a debatable concept in various fields of study. Different researchers discussed about participation and women empowerment in microfinance, self-help groups, policy development, information technology (Ginting and Siregar, 2020; Yadav, 2018; Rudolf, 2019; Jr Edwards, Mathews, Spear \& Hartley, 2020) and provide a lot of contributions. According to Palikhe (2018) indicated that, tourism industry is a multifaceted industry, though the attention of the researcher for the discussion on participation and women empowerment within the industry is very limited. This result a limited number of the study in this field. This study aims to investigate the consistency of participation and women empowerment in tourism industry if it has the same weight in terms of its contribution as attained in other field of studies. Previously, the relationship between participation and society and human development originates during the ancient Greeks by Aristotle. Aristotle did not find any strong relationship between participation and the creation of good life at the societal level. He argued that the relationship will be strong if there would be the rule by the many and respect the individual rights (Cohen \& Uphoff, 1980). This idea recognized in

Copyright (C) 2022 The Author(s): This is an open-access article distributed under the terms of the Creative Commons Attribution 4.0 International License (CC BY-NC 4.0) which permits unrestricted use, distribution, and reproduction in any medium for noncommercial use provided the original author and source are credited. 
community development project and programs since 1970s and 1980s due to the reason of failure of stakeholders to participate in community development projects (Escobar, 1995). Similarly, in the last five decades, the concepts of women empowerment have undergone to see changes from welfare oriented to equity approach (Khan, 2020). Since then the combination of these concepts raised so as to participate in various movement and denying discrimination without any other class dominating others (Cohen \& Uphoff, 1980).

Participation was used very general, recently the researchers adopted participation in relation to women empowerment in different fields of studies. Most of the studies conducted discussed on participation and women empowerment for example, the study conducted in Pakistan by Ejaz and Farooq, (2019); the study of Maliva (2016); Jayswal and Jaiswal (2015) while few of the literatures discussed on the relationship between participation in decision making and women empowerment in economic in tourism industry. To bridge the gap this study based in the context of women working in tourism industry in Zanzibar community. Furthermore, the scope of this study was on three dimensions of participation, participation in decision making, implementation and benefit and in the part of women empowerment three dimensions were also consisted; women economic empowerment, women psychological empowerment and women social empowerment. The study determines the relationship between participation and women empowerment in tourism industry. Specifically, looks on participation in decision making, implementation and participation in benefit in relation to women economic empowerment, psychological and women social empowerment. Section two of this study reviewed various literatures related to study objectives. Section three explained the methodology used. Based on the proposed models from Figure 1 section four present and discuss the statistically findings of the hypotheses, conclusions, limitations and directions for future study.

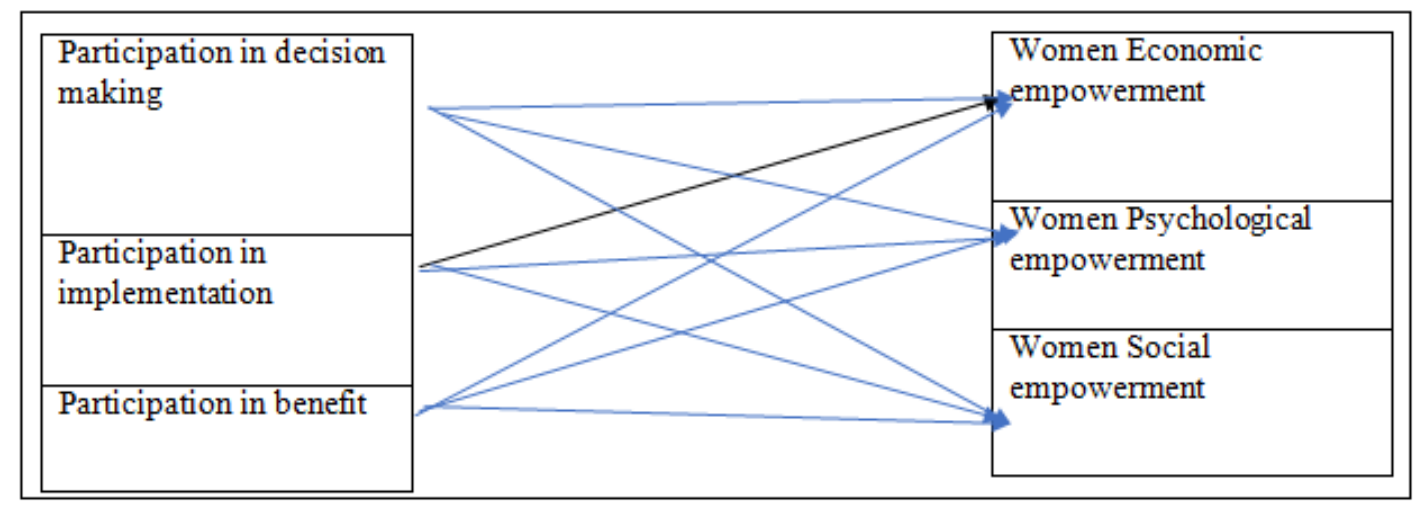

Figure 1: Hypothesised Model

\section{LITERATURE REVIEW \\ Community and Women Participation}

Community participation is a fundamental basic right for a human being (Yang, 2015). Normally, people should be given the opportunity to join in projects to solve their own problems that affect their lives (Mustapha, Azman, and Ibrahim, 2016). Community participation can be defined as the process whereby the community its-self takes responsibility to initiate the resources existing in the community for the development of the society and share decision making for the implementation of other projects established within the society. The general assumption for public participation is the involvement of all beneficiaries who are affected by the decision has the right to provide their ideas in the decision-making process (Yang, 2016). Community participation is developing self-reliance, self-confidence, empowerment, and problem-solving skills (Mansuri and Rao, 2013). People in the society can participate in different approaches, such as top-down approach or bottom-up approach but participation it depends on the factors which influence the degree of community participation like the relevance and accountability, level of education possessed in the community, communication network that society has in order to mingle with various developers existing in the project, economic factors, social and cultural factors (Yang, 2016). The justification for community participation comes through many sources including the challenges and achievements obtained based on programs (Kothari, 2001). Community participation helps to show people rights in society and ensuring the economic benefits from tourism as the program is for the tourism sector and the community depends on it (Scheyvens, 1999).

According to Kinnaird and Hall (1996:100) women has heavy role to play in tourism sector if only this role is recognized and reinforcement as well as construction, the scholars put thus: "Unless we understand the gendered complexities of tourism, and the power relations they involve, then we fail to recognise the reinforcement and construction of new power relations that are emerging out of tourism processes. From the values and activities of the transnational tourist operator to the differential experiences of individuals participating as either hosts or guests, all parts of the tourism experience are influenced by our collective understanding of the social construction of gender". 
Similarly, according to International Labor Union (2001:74) so stresses the opportunities inherent in tourism sector for women quote this report in detail: "They [women] occupy the lower levels of the occupational structure in the tourism labour market, with few career development opportunities and low levels of remuneration (some estimates suggest that wages for women are up to $20 \%$ lower than those for men). The greater incidence of unemployment among women is attributed to their low skill levels and their low social status in many poor countries. They also tend to be the first affected when labour retrenchment occurs as a result of recession or adjustment to new technology. It should also be noted that the majority of workers in subcontracted, temporary, casual or part-time employment are women".

Many kinds of literature describe Community participation in tourism in two viewpoints: the decision-making process and tourism benefits. Scheyvens (2000): Ying and Zhou (2007) indicate that the process of involving people around the community in decision making facilitates the community to get the chance of being empowered in tourism development. The society has the opportunity to express their views and wants towards specific tourism project introduced. Similarly, on the side of the benefit perspective, the people attain employment opportunities that increase their social wellbeing.

The decision-making process in a community project is an essential element for the community. The community obtains opportunities and responsibilities of citizenship (Tosun, 2000) for joining in the process of self-governance, replying to the authoritative decisions that impact people's lives in society and working together with others (Mustapha, Azman, and Ibrahim, 2016). Community participation act as an educational and empowering procedure for the people and for those who participate in assisting them for the purpose of managing the project, by directing to identify the problems, assist to manage and control the project. The community must change the unwanted plan and ensure the best development to fit their needs. In order to facilitate tourism development in our community is better the government and local leaders provide awareness to the society by giving them proper education and information concerning tourism and their benefits (Maliva, 2016). Decision making in tourism development needs a transfer of power between the authoritative leaders and local leaders as both of them to be responsible for their roles (Magigi and Ramadhani, 2013). Meaning that delegation and readjustment of power may facilitate the process to follow the proper way and the community participation may increase besides no domination in the process (Salim and Mwaipopo, 2016).

Stylidis, Biran, Silt, and Szivas (2014) and Bello, Lovelock, and Carr (2016) describe that the main purpose of sustainable tourism development can be achieved by involving people at the grassroots level within the society. Kala and Bagri (2018) recognized that, if there is proper agreement, less chance of delays and more harmonious development and people were encouraged to engage themselves in tourism especially in the primary stage the development must be obtained. Snyman (2012) emphasis that tourism should be community driven, whereby society must take control of their infrastructures and resources available for tourism in their environment. This situation may influence people in the community directly or indirectly to get favourable or unfavourable tourism outcomes. Thus, their participation is important to handle the impacts and to gain benefits generated through tourism (Kala and Bagri, 2018). Women participation is an essential element of the decision making, and plays a key role in their empowerment. For women as Cohen \& Uphoff (1980) suggests, decision making entails their capacity to identify, define, act upon their own objectives and make choices through critical thinking. To date, women participation in tourism industry stands as one of potential opportunities in decision making that may facilitate their empowerment (Sandhya, 2013). One of the most inspiring discussions in community development literature is about women participation in implementation process. Accordingly, implementation process is the stage of doing the community development program or project and make it visible to outsiders. Now, the discussion is inspiring because participation of women in implementation process can make their useful knowledge and expertise visible. This is for the benefits of the entire society (Ruth, 1987). Women Participation in benefits is an interesting phenomenon in community development especially in tourism industry. Many literatures explain participation in benefits as the sharing of welfares obtained through participating in community development programs as the case of tourism activities. As Tosun (2000) described, community participation and involvement ensure the safety measure of these tourism products and services. Timothy (1999); Tosun (2000) shows that the process of sharing and allocating the benefits obtained is the real action and means of participation in the industry. In terms of economic benefits, the society benefited by sharing jobs that facilitate the life standard of stakeholders. According to Chok and Mcbeth (2007), the level of investment in tourism lead to allow local community to benefit from the similar services proven to support tourism. Generally, scholars overlooked to combine all three participation dimensions which participation in decision making, benefit and implementation. This study found the need of incorporating all the three dimensions and observe the combined effect. It worth noted that, there is significant impact toward community development when all the dimensions are considered compared to individual influence.

\section{Women Empowerment}

Empowerment is a vital concept in a community development especially in performing tourism activities in the sense of ensuring peoples wellbeing, self-confidence and esteem. Empowerment is the concept of power. The International Encyclopaedia (1999:33) has defined power as having the capacity and the means to direct one's life 
towards desired social, political and economic goals or status. Consistent to this review, empowerment is what Francina and Joseph (2013) suggest as a multi-dimensional social process in favour of helping people to gain control over own lives, communities and society, by acting on issues of their importance. This conception indicates that empowerment as a process goes together with individual capacity to contemplate, work and act, towards one's own future (Minimol \& Makesh, 2012). The concept of women empowerment has received extensive thought worldwide. The contribution of women in the business world has increased in recent years although women are underrepresented in tourism industry (UNWTO, 2017). Most of African culture took women as a weaker human being made-up to household activities, bearing children and farm work. They defined women by their marriage roles, family and the husbands play a major part in decision making (Ampumuza, 2010). In Tanzania-Zanzibar, The Commission responsible for tourism has given a different dimension to the tourism industries in Zanzibar (ZCT, 2017). Due to the increasing level of education skills, women are coming out to this notion. Though their participation in tourism is very low and they are working at the lower hierarchical positions as unskilled and semiskilled workers (Maliva, 2016). DFID, 2005 defines women empowerment as a "process of transforming gender relations through groups or individuals developing awareness of women's subordination and building their capacity to challenge it". Palikhe, 2018: Aksel et al., 2017: Malhotra, 2002: United Nation Commission on the Status of Women (2002), describe women empowerment as a process in favour of their access to power, rights, resources, voice, ability to control own lives and strategic choices. The study conducted from Pokhara Tourism Office revealed that fifteen percent of women entrepreneurs were engaged in tourism sector, this implies that discrimination of women in this sector is deteriorating.

\section{Economic Empowerment}

From the reviewed literature, economic empowerment is a process and a stage. According to Dutta and Bhakta (2017) the process and stage of economic empowerment is reached through designed strategies in favour of building credit value and financial freedom among women in order to access their correct share in every life aspect. This means that economically enabled women can get enough sustainable income for necessities of life inside or beyond their contexts. In this regard, such women appear to be considerably and necessarily independent on engaging their own potentials towards improved living. From this understanding, it can be reasoned that being economically empowered an individual has to get more income and capacity in deciding economic issues in the community (Moyle, Dollard and Biswas, 2006) and have reason of improving own living quality (Mwamwaja, 2001). To sum up, as economic empowerment conceptualized above a study is proposed to focus on women skills, choice, access to resources and access to income when participating in tourism activities in Zanzibar.

\section{Psychological empowerment \& Social empowerment}

Psychological empowerment is another important variable for this study. According to Zimmerman (1995), psychological empowerment is a sense of control over the individual life, motivation, essential skills and knowledge to facilitate own socio-political condition. It is made up by self-esteem, self-efficacy, self-control, self-determination (Prilleltensky, 2012). Out of those aspects, self-esteem and self-efficacy are known for their thoroughness in facilitating the increase of the wellbeing among individuals and communities (Christens \& Peterson, 2012). This understanding has important implication for individual women mental readiness in income generating projects, and implementing community development (Peterson \& Zimmerman, 2004). In this way, psychological empowerment can lead changes in community's people life through the combination of strategic efforts (Christens, 2012). Based on this observation, it can be reasoned that psychological empowerment has the meaning that can help women to change the extent of being independent on deciding their own important issues of lives. Another variable of consideration is social empowerment. According to Combaz and Mcloughlin (2014) social empowerment is a process of improving power and self-confidence to the people both individually and collectively in the attempts to change their social relationships. This understanding makes social empowerment a wider concept in community development ideologies as it covers the levels of individual, family, community and social policies (Food and Agriculture Organization of the United Nations, 2015).

\section{Tourism Industry}

The United Nation World Tourism Organization shows that tourism can be explained as the "activities of persons travelling to and staying in places outside their usual environment for not more than one consecutive year for leisure, business and other purpose not related to any activities remunerated from within the place visited". Refers to all activities of visitors, including tourists. Guyer Feuler or E. Freuler in 1905 referred as the environment where by people travel outside their home or counties for pleasure to change air and enjoy the nature of scenic beauty, mingling with different people or nations and citizens of different classes in the society for the development of increasing business or commerce and the perfection of the means of transport (Kaul, 2002); Mohd, 2016). Huziker and Krapf in their definition consider tourism as the phenomena which facilitate relationship and leisure from travel but not connected with any earning activities (Robinson, 1976). Similarly, the IASET and the tourism community from Cardiff shows that tourism is not the selected activities that you can make overnight but can be done outside of home environment (Kabia, 2005). Generally, any travel for holidaying, business or professional trip becomes a part of tourism if it is temporary and is 
undertaken voluntarily, without an aim to earn any livelihood out of it (Shodhganga, UWTO, 2017; Devkant and Satish, 2018).

Tourism is one of the fastest growing and most competitive industries in the world (Palikhe, 2018) and is found to be as an important means of empowering women in this present global economy (Praveen and Asokan, 2013). The global research has placed tourism at the heart of decision making in all spheres, political, financial and economic (UNWTO, 2015). It contributes more than 10.9 percent of workforce and generates $\$ 8.8$ trillion to the global economy (Palikhe, 2018). Tourism is acting as a vibrant part in the economy of Zanzibar. The sector accounts estimated of $28 \%$ of the GDP of the island besides 82 per cent of foreign revenue in 2018 (World bank Document, 2019) and provide the highest private sector employment estimated around 22,000 direct and 50,000 indirect jobs (World Travel and Tourism Council Annual Performance Dashboard, 2018). According to the World bank report tourist arrivals in Zanzibar is around 15 percent for the last three years (World Bank Document, 2019). These helps increasing up to 68 percent of tourism investment approved by Zanzibar investment promotion authority and calculate the growth of the economy of Zanzibar through tourism exceeded the Zanzibar Tourism Development Policy of 2003 of getting 500,000 number of tourists in 2020 (World bank document, 2019). The current debate on women empowerment explained in the perspective of leadership, understanding values and rights of women, women position, women representation, freedom to move and benefits in relation to micro finance, self -help group (Duvendack et al., 2014; Upadhyay et al., 2014; Banrejee et al., 2015; Datta, 2015; Garikipati et al., 2016. (Mosedale, 2014). Few literatures discussed about women empowerment in tourism (WTO, 2016). Though it shows contribution in adding the capacity of women to contribute in societal decision making in various programs in tourism sector, having self-confidence and capacity of doing (Aksel et al., (2017); Wyndow, Li, \& Mattes (2013). These scholars show a great contribution in the body of knowledge yet we need to strengthen women empowerment in tourism towards improving the means of empowering women and challenges confronting women through tourism sector. Therefore, in this study the relationship between participation dimensions and women empowerment dimensions in tourism industry should be recognized.

\section{Theory and hypotheses development}

Cohen and Uphoff $(1977 ; 1980)$ developed participation theory framework with four dimensions. These dimensions comprise participation in benefit, participation in decision making, participation in implementation and participation in evaluation. According to Cohen and Uphoff (1977) these four forms function as ideology which establishes the sequence of rural community development activities. One of the issues that emerge from this understanding is that the Cohen and Uphoff classification is inclusive and flexible in nature. In this case, this theory promises a complete framework for analyzing participatory dimension of any rural development program. Besides, this theory can help in answering questions related to the types of participation and involved beneficiaries in the participatory process. According to Blackburn, Jarman \& Brooks (2000) participation in all levels should start at the grass root towards top level in decision making. This is important because it may help community members as observed by Cohen $\&$ Uphoff (1980), to influence the ownership, management and control of their activities.

Consistent to the proposed study, participation theory is employed for the following reasons: First, it is expected to help the researcher to focus on the aspect of women in decision making across the structures within which it occurs in the tourism industry. That may include initial or basic decisions about the project, on-going or daily basis decisions of the project, and operational or leadership selection decisions (Kevin, 1991). Second, this theory seems to address implementation equal to participation based in action (Cohen \& Uphoff, 1980). In this regard, targeted women in tourism expected to participate in resource contribution, administration and co-ordination and program enlistment activities. Third, the theory appears to support the discussion of participation in benefits. For this reason, it is expected to tell what kind of benefits and how are distributed among members, in terms of social or public, material or income generating and personal or tangible benefits (Cohen \& Uphoff, 1980). Fourth, the theory is also aspired because it may help to address participation in evaluation, either through project centered evaluation or informal evaluation (Cohen \& Uphoff, 1980). Therefore, this theory used because of its potentials.

Different scholars discuss about the participation as a means and as an end in many literatures like Buchy et al., 2000: Cleaver, 1999: Goebel, 1998: Ward and Mulender, 1991 and others. The most important thing to be considered is to understand the kind of the purposes that participation can assist; this determine the different and the meaning of participation as a means to an end or an end to its self. Buchy et al., 2000 recognized two themes in the works, they interpreted participation as an approach, a method, an ideology, a specific character for community development, a form of guide (recommendations) and practices involving a community in a general planning activity. Cleaver, 1999: Goebel, 1998: Lane, 1995: Macnaghten and Jacob, 1997: and Williams, 2002 commented that, this could be a précised the meaning of participation as a means and as an end. Macnaghten and Jacob (1997) explain as a value based. The discussion of means and end associated with the efficiency, empowerment and equity. Cleaver (1999) discussed efficiency as participation is like a tool of getting positive result in a project and empowerment and equity as 
participation as concern as a catalyst which motivate people improving their own standard of living and enable social change to the vulnerable group.

Nelson and Wright (1995) introduced the difference between participation as a means and participation as an end where by as a means is achieving the better outcomes of the project in an efficiently and effectively way, while participation as an end discussed as a way of community sets up a process to control its own development. The process of involving and empowering people during the early stage (Participation as a means) is very limited compared to the end (participation as an end) (Nelson \& Wright, 1995). Furthermore, the researcher argued the meaning of participation as a means referred as a preliminary stage as a state of input in developing community project while the participation as an end as the last stage of either directing, doing or provide guidelines to the meaningful participation in a project (Ward \& Mullender, 1991). Therefore, we can summarize by saying participation is a way of achieving the predetermined objectives via social economic resources to enhance predetermined target (Nikkhah \& Redzuan, 2009). For those individuals who make an assessment and see participation as a means to an end insist the poor are engaging themselves for the purpose of safeguarding their own livelihood. If that the case, they cannot afford to participate in any activities unless there are tangible benefit observed (Burkey, 1993). Therefore, participation in the design of the prearranged target (objectives) is more essential compared to the act of participation (Nikkhah \& Redzuan, 2009).

Participation as an end perceived as a bottom-up approach, the process focused on designing or shaping, deciding and implementing the development process. The people were directly involved in taking part of the activities of the project (Abu Samah, 1996 as cited in Nikkah \& Redzuan, 2009). Further argued in the sense of development objectives can be a secondary aim in its importance in the process where by its result leads to meaningful participation in the development process (Moser, 1989; Oakley, 1991 as cited in Nikkah \& Redzuan, 2009). Convincingly, this referred as a direct participation (Richardson, 1983 as cited in Nikkah \& Redzuan, 2009) or active participation (Gilbert \& Ward, 1984 as cited in Nikkah \& Redzuan, 2009) among the individuals whose confidence and competence built (Nikkhah \& Redzuan, 2009). In this sense participation can be defined as a process of accomplishing more individual satisfaction, creating awareness and personal development (Richardson, 1983 as cited in Nikkah \& Redzuan, 2009). Therefore, participation as an end to its self in this study is associated as a process that leads to empowerment. The involvement of people taking part together in community development activities encourage to increase knowledge, skills and experiences and use them for the benefit of him/herself or community or for the benefit of the public in general (Abu Samah and Aref, 2009a). People through participation can be empowered after realizing the ability they have to make changes in respect of their needs when understanding the problem, they have (Abu Samah \& Aref, 2009b).

\section{Empowerment Theory}

The idea of empowerment theory is focused on the outcome after vulnerable group has accessed resources and power (Freire 1973). The theory was developed by Paul Freire, the Brazilian humanitarian and educator. The purpose was to rescue the oppressed citizens through education. The concept of empowerment is interrelated with psychological, economic or social dimensions (Mann, 2006; Zimmerman \& Rappaport, 1988). It has features for individual and collective empowerment (Mann, 2006) and close relationship (Rowland, 1997). Thus, the theory supports ongoing development all through.

In line with this proposed study, empowerment theory was used because it has potentials in studying women participating in tourism industry. In this case, the researcher expects to use it for explaining the strategies common to Zanzibar women in the tourism. Besides, this theory used because of its systematic explanations that can help the researcher to study Zanzibar women empowerment skills in relation to their participation in the tourism sector. In addition to that, the theory used in order to get a better understanding of how women make a decision to selfempowerment and community development. Apart from that, the researcher expects to employ the dimensions of this theory to understand individual's capability in terms of economic, psychological and social control. For instance, through economic empowerment the capacity of women to participate and benefit from tourism sector can be realized. From psychological empowerment, the researcher can focus on its determinants of self-esteem, self-efficacy, self-control, selfdetermination to appreciate their contribution to understand women progress. For social empowerment, the researcher expects to trace women improved power and self-confidence throughout their engagement in tourism activities in Zanzibar.

Relationship between participation and empowerment was explained by Zimmerman (1990) through learned hopefulness whereby the respondents learn and apply skills that help them to encourage a sense of psychological empowerment. Zimmerman argued that the involvement in community activities significantly improves one's problemsolving and control over the social environment. This implies that, participation in community activities has a positive and direct effect on psychological empowerment. The study conducted by Christens, Peterson, \& Speer (2011) researched on evaluation of impacts of fives community organizing initiatives affiliated with the People Improving Communities (PICO) in Middle East, East and Western USA. The study aimed to assessed individuals' in volvement and 
participatory behaviours in community initiatives. The Author sought to elucidate the relationship between community participation in decision making to psychological empowerment, is a quantitative study using structural equation model with two waves of survey data from a cross-lagged panel to test randomly selected neighbourhood residents and organisational members from United states. The result indicated that, there is significant relationship of community participation in decision making to psychological empowerment. Also Christens, Peterson, \& Speer revealed that community participation in implementation also significantly related to psychological empowerment. Several studies show the relationship between community participation and psychological empowerment, the study of Kieffer's (1984) concerning with empowerment among leaders in grassroots organisation explained that empowerment as a development process encompassing cognitive and behavioural change. This study is in line with the study of Speer and Hughey's (1995) researched on ecological empowerment through community indicated the relationship between community participation and psychological empowerment. The existing study encompasses the previous study by investigating the relationship between participation dimensions and women empowerment dimensions. Few existing studies on Psychological empowerment use experimental designs and cross-lagged analysis to test the relationship between participation and empowerment. Specifically, nor prior study has used multistage cluster sampling design and partial least square (PLS Algorithms) analysis to testify the relationship between participation and empowerment in tourism industry.

The study conducted in Burkina Faso on the relationship between women's socioeconomic status and empowerment a focus on participation in decision making and experience of domestic violence by using binary logistic regression indicated that women's participation in household decision making influence the relationship between economic empowerment. In this study women participate in decision making on visiting their family, women decide for their own health and important purchases. Furthermore, it revealed that the women with education and older age participate more in decision making are more empowered in making household purchasing decision this implies that the status of household economy increased by involving women (Pambe et al., 2014). Furthermore, the study of participation in self-help groups and empowerment of women; a structural model analysis conducted by Nayak and Panigrahi (2020) with the aim to examine the level of participation and economic empowerment, the findings suggest that the relationship between level of participation in self-help group results in enhanced economic empowerment by its members by bringing in employment opportunities, higher incomes, stability in current jobs and improved entrepreneurial abilities. The author argued that higher participation leads to provide an increased social empowerment of respondents in the form of decision-making capability in the communities, self-confidence, higher self-esteem and the respondents capacity of transact money with banks or non-government organisation. The study on participation in microfinance as a medium of empowerment conducted in Nigeria in kano state (Saidu, 2014) aimed to determine the relationship between participation dimensions and empowerment dimensions, by using the structural model, the findings indicated that participation in decision has significantly related to social empowerment, participation in implementation has significantly related to social empowerment, and participation in benefits has significantly related to social empowerment. This is in agreement with the study on community development initiatives in India researched by Bali Swain and Wallentin (2012) shown that participation in decision making has significantly related to social attitudes participation in implementation has significantly related to social attitudes and participation in benefits has significantly related social attitudes This implies that women involvement in community development initiatives in India creates self-confidence and change social attitude of the respondents and this is what we said social empowerment in the community (Bali Swain \& Wallentin, 2012). From the review of the above scholarly works, the following hypotheses were developed:

$H_{0_{1}}$ : Participation in benefit has no significant relationship with women economic empowerment

$H_{0_{2}}$ : Participation in benefit has no significant relationship with women psychological empowerment

$H_{0_{3}}$ : Participation in benefit has no significant relationship with women social empowerment

$H_{0_{4}}$ : Participation in decision making has no significant relationship with women economic empowerment.

$H_{0_{5}}$ : Participation in decision making has no significant relationship with women psychological empowerment.

$H_{0_{6}}$ : Participation in decision making has no significant relationship with women social empowerment.

$H_{0_{7}}$ : Participation in implementation has no significant relationship with women economic empowerment

$H_{0_{8}}$ Participation in implementation has no significant relationship with women psychological empowerment

$H_{0_{9}}$ : Participation in implementation has no significant relationship with women social empowerment

\section{Materials ANd Methods}

The participants consisted of active women who participate in tourism industry having thirty-five years and above. In this quantitative study, Krejcie and Morgan (1970) table were used to determine a sample. The estimated sample size was 375 at alpha 0.05 level of significance (95\% level of confidence). The researcher adds $10 \%$ of sample size of the respondents to avoid drop out. Therefore, the required sample size was 412 in order to reduce a sampling error and ensuring more representativeness (Singh and Masuku, 2013). The multistage cluster sampling technique was used to select the respondents from nine wards in Zanzibar. The Wards include Mkoani Mjini, Makombeni, Wambaa, Madungu, 
Wesha, Utaani, Limbani, Fundo and Makangale. The structured questionnaire was used as an instrument for data collection and the questionnaire was distributed to 412 respondents (women) who participate in tourism activities among them 387 fulfil the criteria and used to undertake the final analysis.

\section{Measures}

The research instrument was adopted and modified from the existing literature to measure participation dimensions and women empowerment dimensions. Ten items (10) of participation in decision making, nine (9) items of participation in implementation, eleven (11) items of participation in benefit. All the items of participation dimensions were developed by World Bank (2008): Greeley, \& Chaturvedi (2007). Sample of the questions include for participation in decision making, "I decide on my own on how to manage my tourism activities and products". "I decide on my own the kind of materials that I'm using to market my tourism products". For participation in implementation, "I used to go to appropriate person or place to ask question on what I need to know on how to improve my skills as well as marketing strategy". "I apply my knowledge that I have learnt at tourism training on my tourism activities". For participation in benefit the sample of items include "As a result of participating in tourism sector, I have developed social network with different friends". "As a result of participating in tourism sector, I have developed ideas on marketing my tourism product".

Eleven (11) items of Women economic empowerment adopted and modified from Kabeer, 1999; Vida, 2011; Ndaeji (2014), the sample of the items was, "I learn how to manage my financial resources now". "I have gained employable skills from my participation in tourism activities" nine (9) items of Women psychological empowerment modified and adopted from Cheung, Mok, Cheung, 2005, Ndaeji (2014), some of the sample questions, "I am more confident than before". "I'm valued and respected in my community now". 10 items of Women social empowerment adopted and modified from Sambangi, 2009; Moyle, Dollard and Biswas, 2006, Ndaeji, 2014. The sample questions include, "I feel better making decision about my-self'." I can act about my own now". "My children have access to good education now".

Five-point Likert scale ranged from $1=$ strongly disagree to $5=$ strongly agree for both dimensions were used. The respondents were anticipated to point out the extent to which they disagree or agree with each statement.

\section{RESULTS}

The preliminary test of the model was conducted to confirm the multivariate assumptions. Precisely, the outlier was evaluated using Mahalanobis Distance (D2) and the result showed that there are non-outliers. The reason behind this was because the data collected from a single source, three statistical preparations were introduced to tackle the effect of common method variance (CMV). First by receiving expert opinion through content validity of the items and second by using the Harman's single factor test (Podsakoff et al., 2012). The result indicated that no single factor reported more than $50 \%$ of the variance (Podsakoff et al., 2012). This explain the meaning of absence of Common Method Bias in this study. Third, multicollinearity was assessed using tolerance value and variance inflated factor (VIF) through regression results from SPSS. The result showed that tolerance and variance inflated factor was in line with the assumptions.

\section{Models assessment}

PLS-SEM used to determine the inner and outer models. Specifically, is very appropriate for this research because it has few limitations on multivariate normality assumptions and suitable for exploratory models and theory development. The content of all the model assessment indices is complete in the software, compared to other software such as Warp-PLS (Kumar and Purani, 2018). The measurement models evaluated by using two stage approach (Hair et al., 2010) in Partial least square structural model (PLS-SEM) using Smart-PLS 3. It was used to create an interactions effects which was calculated in Smart-PLS 3.2. The size and direction of the path coefficients was examined through PLS-SEM Algorithm and the significance of the relationship was examined through PLS-SEM bootstrapping procedure in the SmartPLS 3.2. (Hair et al., 2013; Hair, et al., 2012; Hair, Ringle, \& Sarstedt, 2011; Henseler et al., 2009). significant value at $\mathrm{p}<0.01$ and $\mathrm{p}<0.05$. The results in Table 1 present the convergent validity and reliability. Similarly, the result in Table 3 indicate the discriminant validity of the measures.

\section{Measurement model assessment}

The outer model verifies the validity and reliability (Haier et al., 2012). In order to assess the outer model, it was recommended to look at the indicator loadings, composite reliability, average variance extracted and rho A. This measure the values of convergent validity if are true or not representative of the construct. As indicated in Table 1 and figure number 2 . 


\begin{tabular}{|c|c|c|c|c|c|c|}
\hline Constructs & Items & $\begin{array}{l}\text { Loadi } \\
\text { ngs }\end{array}$ & $\begin{array}{l}\text { Cronbach's } \\
\text { Alpha }\end{array}$ & rho_A & $\begin{array}{l}\text { Composite } \\
\text { Reliability }\end{array}$ & $\begin{array}{l}\text { Average Variance } \\
\text { Extracted (AVE) }\end{array}$ \\
\hline \multirow{7}{*}{$\begin{array}{l}\text { Benefit of } \\
\text { Participation }\end{array}$} & PB1 & 0.718 & 0.852 & 0.862 & 0.888 & 0.534 \\
\hline & PB2 & 0.838 & & & & \\
\hline & PB3 & 0.590 & & & & \\
\hline & PB4 & 0.724 & & & & \\
\hline & PB5 & 0.735 & & & & \\
\hline & PB8 & 0.667 & & & & \\
\hline & PB9 & 0.816 & & & & \\
\hline \multirow{8}{*}{$\begin{array}{l}\text { Participation in } \\
\text { Decision Making }\end{array}$} & PDM10 & 0.601 & 0.866 & 0.871 & 0.895 & 0.518 \\
\hline & PDM2 & 0.733 & & & & \\
\hline & PDM3 & 0.769 & & & & \\
\hline & PDM5 & 0.788 & & & & \\
\hline & PDM6 & 0.706 & & & & \\
\hline & PDM7 & 0.635 & & & & \\
\hline & PDM8 & 0.767 & & & & \\
\hline & PDM9 & 0.737 & & & & \\
\hline \multirow{9}{*}{$\begin{array}{l}\text { Participation in } \\
\text { Implementation }\end{array}$} & PIMPL1 & 0.759 & 0.891 & 0.898 & 0.912 & 0.536 \\
\hline & PIMPL2 & 0.754 & & & & \\
\hline & PIMPL3 & 0.632 & & & & \\
\hline & PIMPL4 & 0.598 & & & & \\
\hline & PIMPL5 & 0.772 & & & & \\
\hline & PIMPL6 & 0.788 & & & & \\
\hline & PIMPL7 & 0.767 & & & & \\
\hline & PIMPL8 & 0.760 & & & & \\
\hline & PIMPL9 & 0.735 & & & & \\
\hline \multirow{8}{*}{$\begin{array}{l}\text { Economic } \\
\text { Empowerment }\end{array}$} & WEE1 & 0.719 & 0.890 & 0.894 & 0.912 & 0.565 \\
\hline & WEE10 & 0.793 & & & & \\
\hline & WEE11 & 0.764 & & & & \\
\hline & WEE3 & 0.743 & & & & \\
\hline & WEE4 & 0.726 & & & & \\
\hline & WEE6 & 0.656 & & & & \\
\hline & WEE7 & 0.796 & & & & \\
\hline & WEE9 & 0.806 & & & & \\
\hline \multirow{8}{*}{$\begin{array}{l}\text { Psychological } \\
\text { Empowerment }\end{array}$} & WPSYE1 & 0.804 & 0.881 & 0.895 & 0.904 & 0.543 \\
\hline & WPSYE2 & 0.792 & & & & \\
\hline & WPSYE3 & 0.757 & & & & \\
\hline & WPSYE4 & 0.727 & & & & \\
\hline & WPSYE5 & 0.733 & & & & \\
\hline & WPSYE6 & 0.706 & & & & \\
\hline & WPSYE8 & 0.694 & & & & \\
\hline & WPSYE9 & 0.670 & & & & \\
\hline \multirow{8}{*}{$\begin{array}{l}\text { Social } \\
\text { Empowerment }\end{array}$} & WSE1 & 0.722 & 0.887 & 0.902 & 0.911 & 0.567 \\
\hline & WSE10 & 0.527 & & & & \\
\hline & WSE2 & 0.825 & & & & \\
\hline & WSE3 & 0.854 & & & & \\
\hline & WSE5 & 0.846 & & & & \\
\hline & WSE6 & 0.835 & & & & \\
\hline & WSE7 & 0.685 & & & & \\
\hline & WSE8 & 0.670 & & & & \\
\hline
\end{tabular}




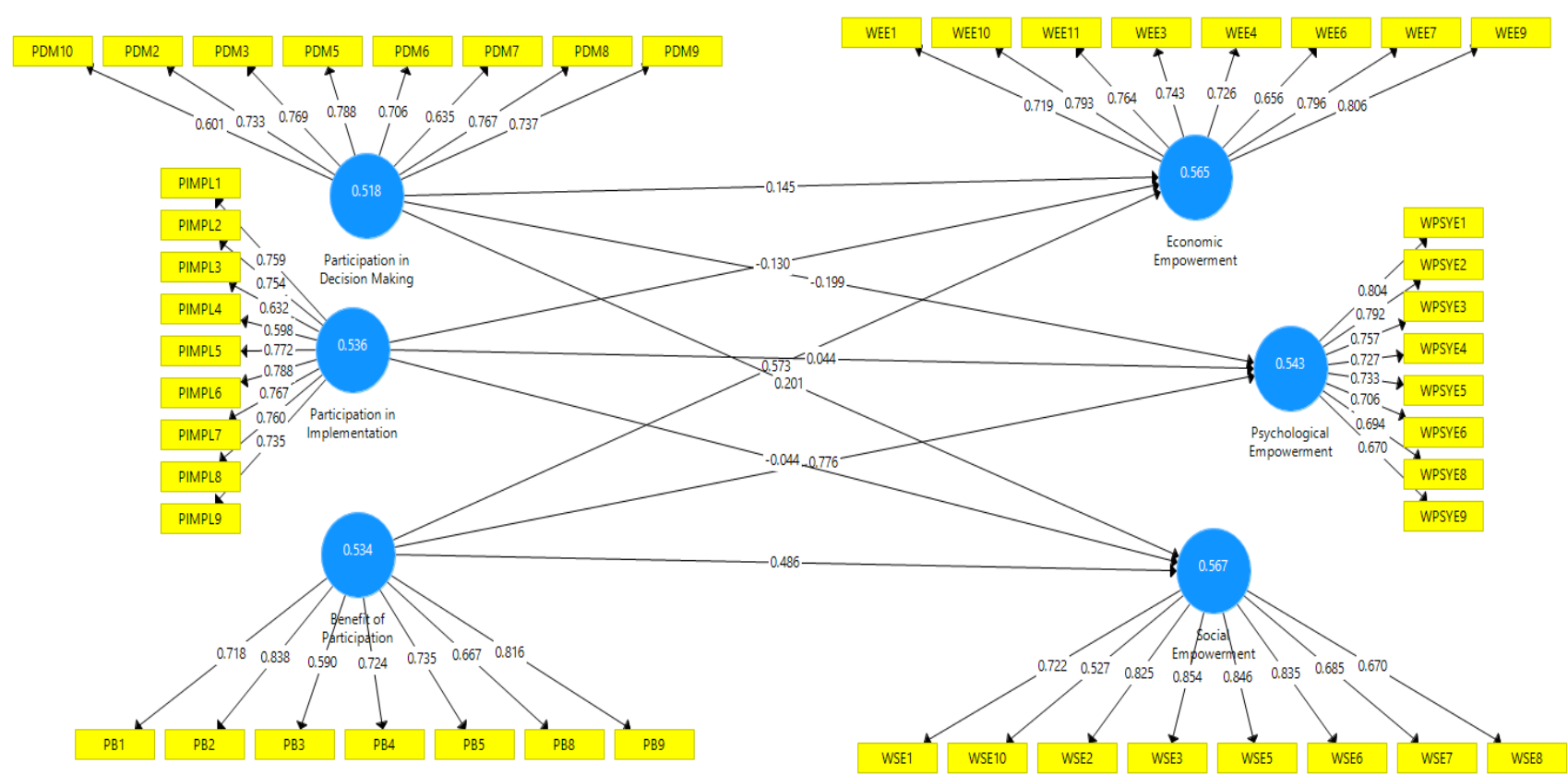

Figure 2

The indicator loadings were all above the threshold, most of them were at 0.6 and few of them were around 0.5 but both are within the threshold as Hair et al., 2010 proposed. Cronbach alpha values, rho A values, composite reliability values were all above 0.7 and the AVE values were also above the 0.5 ; this indicated that the convergent validity was attained. Discriminant validity was measured to show the uniqueness of the items of the constructs from other constructs within the model. The heterotrait-monotrait ratio (HTMT) method was used to measure the discriminant validity. The result discovered the confirmation of discriminant validity through the recommendation of (Henseler et al., 2015). All the items indicated in the Table 2 confirm the threshold of both 0.9 (Kline) and 0.8 (Gold et al., 2001). The results further explained that no values exceed the threshold while the upper limit confidence interval were all less than one. This result confirms the achievement of discriminant validity.

Table 2: HTMT

\begin{tabular}{|l|l|l|l|l|l|}
\hline $\begin{array}{l}\text { Benefit of Constructs } \\
\text { Participation }\end{array}$ & $\begin{array}{l}\text { Economic } \\
\text { Empowerment }\end{array}$ & $\begin{array}{l}\text { Participation in } \\
\text { Decision Making }\end{array}$ & $\begin{array}{l}\text { Participation in } \\
\text { Implementation }\end{array}$ & $\begin{array}{l}\text { Psychological } \\
\text { Empowerment }\end{array}$ \\
\hline Benefit of Participation & & & & \\
\hline Economic Empowerment & 0.822 & & & & \\
\hline $\begin{array}{l}\text { Participation in Decision } \\
\text { Making }\end{array}$ & 0.808 & 0.782 & & & \\
\hline $\begin{array}{l}\text { Participation in } \\
\text { Implementation }\end{array}$ & 0.838 & 0.750 & 0.848 & & \\
\hline $\begin{array}{l}\text { Psychological } \\
\text { Empowerment }\end{array}$ & 0.663 & 0.611 & 0.414 & 0.439 & \\
\hline Social Empowerment & 0.770 & 0.837 & 0.692 & 0.633 & 0.512 \\
\hline
\end{tabular}

\section{Structural Model Assessment}

In structural model assessment, the model is concerning with dependent links that join the constructs in the hypothetical model (Haier et al., 2014). Mostly it shows the interrelations between the constructs and realize the proof supporting the theoretical model. The model determines the relations between independent and dependent latent variable and its relationship were assessed through inner model which is participation dimensions and women empowerment dimensions. To measure the inner models, the beta values, t-values by using the bootstrapping procedures with 5000 resample, coefficient of determination ( $R$ square), predictive relevance ( $Q$ square) and the effect sizes (f square) were evaluated. As indicated in Table 3 and Figure 3, participation in benefit was positively related to economic empowerment and psychological empowerment $(\beta=0.573, \mathrm{t}=8.156, \mathrm{p}=0.00),(\beta=0.776, \mathrm{t}=10.418, \mathrm{p}=0.00)$ while participation in benefit were not related with social empowerment respectively and hence $\mathrm{H} 1$ and $\mathrm{H} 2$ were supported while $\mathrm{H} 3$ were not supported. Participation in decision making were significantly related with economic empowerment and social empowerment $(\beta=0.145, \mathrm{t}=2.363, \mathrm{p}=0.009) ;(\beta=0.201, \mathrm{t}=2.455, \mathrm{p}=0.007)$ respectively. The result shows that participation in decision making were not significant related to psychological empowerment $(\beta=-0.199, \mathrm{t}=2.269, \mathrm{p}=$ 0.012). Therefore, H4 and H6 were supported while H5 were not supported. Furthermore, participation in 
implementation, the result showed that there is no significant relationship between participation in implementation and economic empowerment, psychological empowerment, social empowerment $(\beta=-0.130, \mathrm{t}=2.121, \mathrm{p}=0.017)$; $(\beta=$ $0.044, \mathrm{t}=0.509, \mathrm{p}=0.306) ;(\beta=-0.044, \mathrm{t}=0.649, \mathrm{p}=0.25)$ respectively and hence $\mathrm{H} 7, \mathrm{H} 8, \mathrm{H} 9$ were not supported.

The study measures the quality of structural model and was found that the predictive accuracy the portion of economic empowerment, psychological empowerment and social empowerment are presented in the Table 4 which are 64, 36 and 48 per cent respectively, this indicate the model has satisfactory R square. The model was above the threshold as recommended by Cohen, 1998 categorisation (0.26 substantial, 0.13 as moderate and 0.02 as weak). The effect size (f2) which shows the individual contribution of independent variable to dependent variable indicate satisfactory as recommended by Cohen, (1998) 0.02 as weak, 0.15 as moderate and 0.35 as large as shown in the Table 5 .

Table 3: Result of Hypotheses Testing

\begin{tabular}{|l|l|l|l|l|l|l|l|}
\hline & & & & & \multicolumn{2}{l|}{$\begin{array}{l}\text { confidence } \\
\text { Intervals }\end{array}$} & \\
\hline Relationships & $\begin{array}{l}\text { Std. } \\
\text { Beta }\end{array}$ & $\begin{array}{l}\text { Std. } \\
\text { Error }\end{array}$ & t-values & $\begin{array}{l}\text { p- } \\
\text { values }\end{array}$ & $\begin{array}{l}5.00 \\
\%\end{array}$ & $\begin{array}{l}95.00 \\
\%\end{array}$ & Decision \\
\hline $\begin{array}{l}\text { Benefit of Participation -> Economic } \\
\text { Empowerment }\end{array}$ & 0.573 & 0.070 & 8.156 & 0.000 & 0.440 & 0.675 & Supported \\
\hline $\begin{array}{l}\text { Benefit of Participation -> Psychological } \\
\text { Empowerment }\end{array}$ & 0.776 & 0.074 & 10.418 & 0.000 & 0.650 & 0.889 & Supported \\
\hline $\begin{array}{l}\text { Benefit of Participation -> Social } \\
\text { Empowerment }\end{array}$ & 0.486 & 0.079 & 6.159 & 0.000 & 0.365 & 0.630 & $\begin{array}{l}\text { Not } \\
\text { Supported }\end{array}$ \\
\hline $\begin{array}{l}\text { Participation in Decision Making -> } \\
\text { Economic Empowerment }\end{array}$ & 0.145 & 0.061 & 2.363 & 0.009 & 0.031 & 0.233 & Supported \\
\hline $\begin{array}{l}\text { Participation in Decision Making -> } \\
\text { Psychological Empowerment }\end{array}$ & -0.199 & 0.088 & 2.269 & 0.012 & - & -0.069 & $\begin{array}{l}\text { Not } \\
\text { Supported }\end{array}$ \\
\hline $\begin{array}{l}\text { Participation in Decision Making -> Social } \\
\text { Empowerment }\end{array}$ & 0.201 & 0.082 & 2.455 & 0.007 & 0.063 & 0.326 & Supported \\
\hline $\begin{array}{l}\text { Participation in Implementation -> } \\
\text { Economic Empowerment }\end{array}$ & -0.130 & 0.061 & 2.121 & 0.017 & - & -0.031 & $\begin{array}{l}\text { Not } \\
\text { Supported }\end{array}$ \\
\hline $\begin{array}{l}\text { Participation in Implementation -> } \\
\text { Psychological Empowerment }\end{array}$ & 0.044 & 0.086 & 0.509 & 0.306 & - & 0.181 & $\begin{array}{l}\text { Not } \\
\text { Supported }\end{array}$ \\
\hline $\begin{array}{l}\text { Participation in Implementation -> Social } \\
\text { Empowerment }\end{array}$ & -0.044 & 0.068 & 0.649 & 0.258 & - & 0.076 & $\begin{array}{l}\text { Not } \\
\text { Supported }\end{array}$ \\
\hline
\end{tabular}

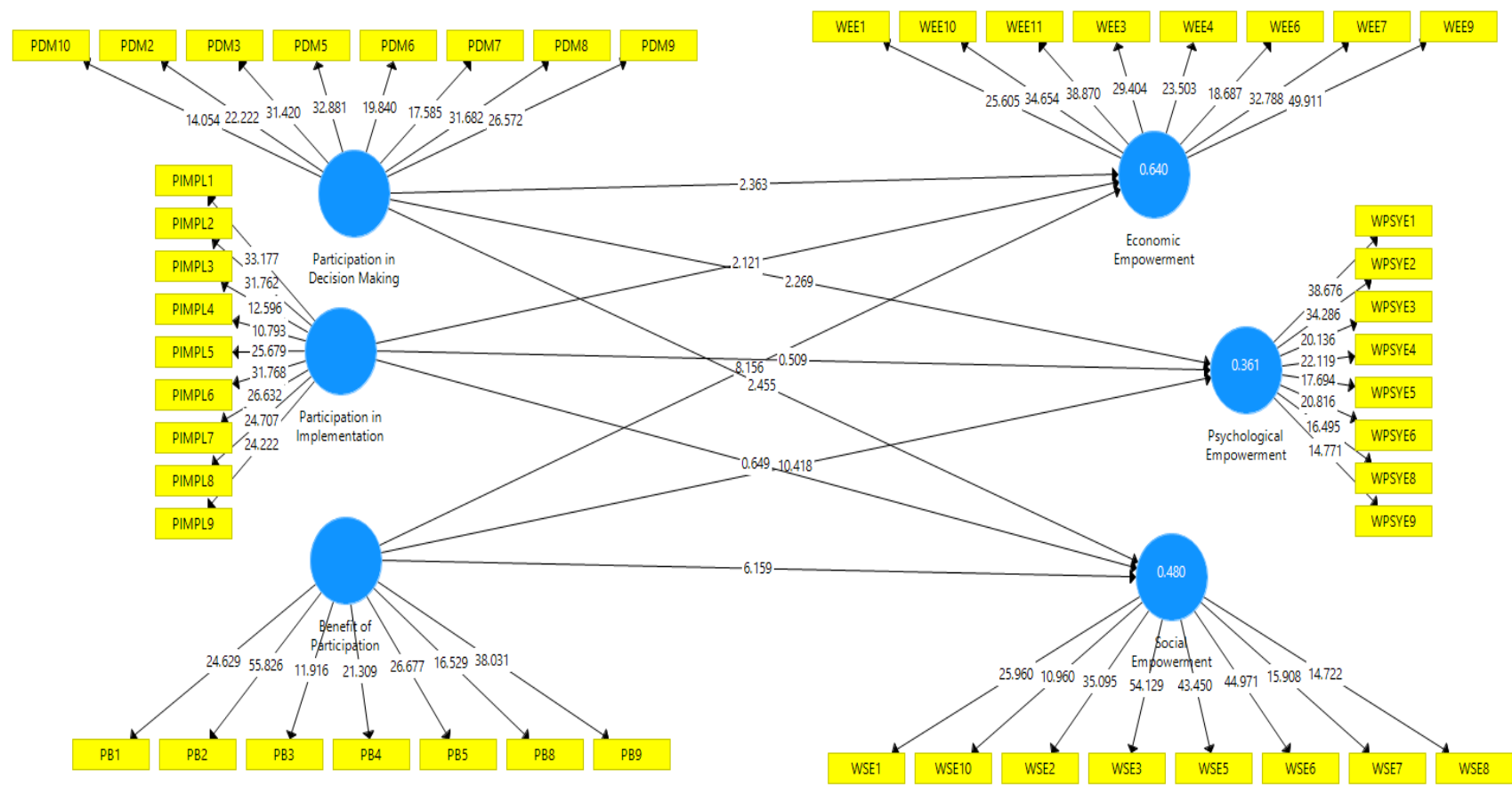

Figure 3 
Table 4: R2

\begin{tabular}{|l|l|}
\hline Constructs & R Square \\
\hline Economic Empowerment & 0.640 \\
\hline Psychological Empowerment & 0.361 \\
\hline Social Empowerment & 0.480 \\
\hline
\end{tabular}

Table 5: Effect Size (f2)

\begin{tabular}{|l|l|l|l|}
\hline $\begin{array}{l}\text { Benefit of Constructs } \\
\text { Participation }\end{array}$ & $\begin{array}{l}\text { Economic } \\
\text { Empowerment }\end{array}$ & $\begin{array}{l}\text { Psychological } \\
\text { Empowerment }\end{array}$ & $\begin{array}{l}\text { Social } \\
\text { Empowerment }\end{array}$ \\
\hline Benefit of Participation & 0.29 & 0.3 & 0.144 \\
\hline Participation in Decision Making & 0.017 & 0.019 & 0.023 \\
\hline Participation in Implementation & 0.015 & 0.001 & 0.001 \\
\hline
\end{tabular}

\section{DISCUSSION}

The constructs of participation dimension (decision-making, benefit and implementation) and women empowerment dimensions (economic empowerment, psychological and social) has been suggested as the concepts which determine the relationship among themselves (Cohen \& Upphof, 1980; Zimmerman, 1990). Participation of women in tourism industry depict the increasing of financial increase, self-esteem, and confidence for women. This helps the respondents to clear the gap of social welfare and satisfaction. In the present study the findings observed that, participation in decision making, and participation in benefit has significant relation to economic empowerment, because of the involvement of women to provide their ideas concerning tourism matters and sharing benefit, this facilitate women having confidence and self-employed so as to increase their wellbeing (Foltrell et al., 2013; Wijesundara and Wimalaratana (2016). The study argument is supported with Saidu (2014); Akinlabi (2011) study which explored significant contribution of microfinance organizations to alleviate poverty through the increment of income and change their life standards. These rationale lead women to increase more participation in tourism activities so as to improve material gain and this is the reason their participation is high. This is supported with the study of Saidu (2014); Akinlabi (2011); the result indicated the significant contribution of microfinance organizations to alleviate poverty through the increment of income and change their life standards. Besides, participation in implementation indicate non-significant relationship to economic empowerment, which is contrary to (Foltrell et al., 2013; Wijesundara and Wimalaratana, 2016).

The hypothesis emphasised on the relationship between participation in benefit and psychological empowerment. The result of the present study shows that participation in benefit was significant positive related to psychological empowerment. This finding means that the respondents gain control over life through active participation in tourism activities as Cohen \& Uphoff, 1980 said the community members should be involved in different level of participation to ensure such activities has direct and positive impact to the respondent's lives, increase of wellbeing (Christens, 2012) provide self-control of individual life, motivation, essential skills, self-efficacy and self-determination This is in line with the study of Ani et al. (2018) who argued that participation in benefit in tourism sector has positive relation to psychological empowerment. Also, the hypothesis does not focus on the relationship between participation in decision making and psychological empowerment, and the relationship between participation in implementation to psychological empowerment which is contrary to the study of Ani et al., (2018); as well as the study of (Cohen \& Uphoff, 1980) which indicated that, the involvement of people or community in any level increase the self-confidence, esteem, control and improve the lives of the members in the community. This could be lack of proper planning and nonfunding, skills acquisition that can motivate women to increase self-reliance and control.

In addition, the result of this research shows that there was significant relationship between participation in decision making and social empowerment. This finding means that to be self-confidence, develop quality of life, having power and life satisfaction of women requires involvement in tourism, in the sense of making decision this influence empowerment socially. This is similar with the study of (Palikhe, 2018; Jayswal and Jaiswal, 2015; Praveen and Asokan, 2013; Panilage, 2010) who found a positive relation among participation in decision making in tourism industry and social empowerment.

\section{CONCLUSION}

In summary participation in decision making has significant relation with economic empowerment, participation in implementation and participation in benefit has significantly contributed to economic empowerment. Furthermore, analysis through findings also indicated that there is no significant relationship on participation in decision making and implementation while participation in benefit to psychological empowerment significantly relation to psychological empowerment implementation and benefit, and participation in decision making has significant relation to social empowerment, participation in benefit has significant contribution to social empowerment. The study recommends to 
local, international NGO's, women development partners as well as government institutions to strengthen the awareness and capacity building to women working in tourism industry. In order to enable the women community to benefit from tourism industry a number of measures must be taken by the government and community its self to obtain the sustainable tourism business: There is a need to mobilize women community to know the importance of participating in tourism activities and women empowerment. This will influence and build the positive attitudes, harmony which resulting on developing capacity of establishing the tourism community groups. Training and education should also need to enhance economic, social, and psychological welfare. Involvement of women community in planning, development and implementation of tourism activities is highly encouraged. This can be done by organizing seminars and workshops. Government, International NGOs and business partners must be encouraging to provide funds for the stakeholders. Also, there is a need for the community to change behavior and attitude towards tourism industry and should have positive attitude and feel tourism industry is like any other activities that help people to increase their well-being. Financial intermediaries should support women through tourism development. Therefore, they have to participate in decision making, in sharing benefit as well as in implementation in order to get empowered. It is worth to stress that efforts taken on to build the capability of women to participate in decision making and implementation is not significant particularly in building women inner gains such as self-confidences and self-esteem and social empowerment. Future studies still needed in the area of participation in evaluation and women political empowerment in tourism industry.

\section{Limitations and directions for future studies}

Cohen and Uphoff brings out four dimensions of participation. Participation in decision making, implementation, benefit and evaluation. The current study used only three dimensions among four dimensions developed from the Cohen and Uphoff participation theory. Therefore, the researcher recommends other studies on participation in evaluation in relation to women empowerment. The existing study was used for determining the direct relationship between participation (decision making, implementation and benefits) on women empowerment (economic, psychological and social). Additional research is required to determine the moderating role of collectivism on the relationship between participation dimensions and women empowerment dimensions. The study covers only women participating in tourism activities in Zanzibar community. Therefore, the further study is recommended to use both gender (male and female) to get the statistical data that show the extent of male and female participation in tourism industry. The findings of the study revealed that participation in decision making and implementation was not significant to psychological empowerment. Other researcher is needed to explain the challenges faces the dimensions and recommend other possible solutions to overcome the problem.

\section{REFERENCES}

- Adeleke, O. A. (2020). Participation in social group and wellbeing status of rural women in Oyo state, Nigeria. Journal of Agricultural Extension, 24(1). http://dx.doi.org/10.4314/jae.v24i1.2

- Akinlabi, B. H. (2011). Impact of Microfinance on Poverty Alleviation in Nigeria: An Empirical Investigation. European Journal of Humanities and Social Sciences, 2 (1), 97 - 111. Retrieved From https://www. findevgateway.org/paper/2011/01/impact-microfinance-poverty-alleviation-nigeria-empirical-investigation.

- Aksel, S., Pamela, P., Yi-Ting, W., \& Staffan, L. (2017). Women's Political Empowerment: A New Global Index, 1900-2012. World Development, 94, 321-335. http://dx.doi.org/10.1016/j.worlddev.2017.01.061

- Amoah, P. A. (2018). Social participation, health literacy and health and wellbeing: A cross sectional study in Ghana. SSM- Population Health, 4, 263-270. http://dx.doi.org/10.1016/j.ssmph.2018.02.005

- Ampumuza, C. (2010). Women empowerment through Community-based and rural tourism: An Actor network Perspective. Kabale University. Retrieved From https://www.researchgate.net/publication/321334162 Women_Empowerment_through_Community-based_and_Rural_Tourism_An_Actornetwork_Perspective

- Ani, F., Ramlan, N., Yousff, R., \& Damin, Z. A. (2018). Measuring the level of Participation and its relationship with Psychological empowerment through community-based organisation activities. International Journal of Academic Research in business and social sciences. http://dx.doi.org/10.6007/IJARBSS/v8-i8/4621

- Bali, S., \& Wallentin, F. (2012). Factors empowering women in Indian self-help group programs. International Review of Applied Economics, 26(4), 425-444. https://doi.org/10.1080/02692171.2011. 595398

- Banerjee, A., Duflo, E., Glennerster, R., \& Kinnan, C. (2015). The miracle of microfinance: Evidence from a randomized evaluation. Am. Econ. J. Appl. Econ. 7, 22-53. http://dx.doi.org/10.1257/app.20130533

- Bello, F., Lovelock, B., \& Carr, N. (2016). Enhancing community participation in tourism planning associated with protected areas in developing countries: Lessons from Malawi. Tourism and Hospitality Research, 18(3), 309-320. https://doi.org/10.1177/1467358416647763

- Cheung, Y., Mok, B., \& Cheung, T. (2005). Personal empowerment and life satisfaction among self-help group members in Hong Kong. Small group research, 36(3): 354-377. http://dx.doi.org/10.1177/1046496404272510

- Chok, S., \& Macbeth, J. (2007). Tourism as a tool for poverty alleviation: a critical analysis of pro-poor tourism and implications for sustainability. Journal of Current issues in Tourism, 10, 144-166. http://dx. doi.org/10.2167/cit303 
- Christens, B. D. (2012). Targeting empowerment in community development: A community psychology approach to enhancing local power and well-being. Community Development Journal, 47(4), 538-554. http://dx.doi.org/10.1093/cdj/bss031

- Christens, B., \& Peterson, N. (2012). The role of empowerment in youth development: A study of socio-political control as mediator of ecological systems' influence on developmental outcomes. Journal of Youth and Adolescence, 41(5), 623-635. http://dx.doi.org/10.1007/s10964-011-9724-9

- Christens, B., Peterson, N., \& Speer, P. W. (2011). Community participation and psychological empowerment: testing reciprocal causality using a cross-lagged panel design and latent constructs. Health Education \& Behavior, 38(4), 339-347. https://doi.org/10.1007/s10964-011-9724-9

- Cohen, J., \& Uphoff, N. (1980). Participation's Place in Rural Development: Seeking Clarity through Specificity. World Development, 8, 213-235. Retrieved From https://ideas.repec.org/a/eee/wdevel/ v8y1980i3p213-235.html

- Combaz, E., \& Mcloughlin, C. (2014). Voice, empowerment and accountability: Topic guide. Birmingham: GSDRC, university of Birmingham. Retrieved From https://gsdrc.org/topic-guides/voice-empowerment-andaccountability/

- Datta, U. (2015). Socio-economic impacts of JEEViKA: a large-scale self-help group project in Bihar, India. World Dev, 68, 1-18. http://dx.doi.org/10.1016/j.worlddev.2014.11.013

- Devkant kala and Satish Chandra bagri. (2018). Barriers to local community participation in tourism development from mountainous state Uttarakhand, India. Original scientific paper, 66(3), 318-333. Retrieved From https://www.researchgate.net/publication/328064696_Barriers_to_local_community_participation_in_tourism_devel opment_Evidence_from_mountainous_state_Uttarakhand_India/link/5bb5bf3492851ca9ed37ac10/download.

- DFID. (2005). Evaluation of DFID Development Assistance: Gender Equality and Women's Empowerment Phase II Thematic Evaluation: Voice and Accountability. Retrieved From http://www.dfid.gov.uk /Documents/publications1/evaluation/wp7.pdf

- Dutta, N., \& Bhakta, K., (2017). Women Empowerment: Dimensions, Needs and Hurdles in India IMS Business School, Doctoral Colloquium. Retrieved From http://www.managejournal.com/up/conference/20170210 152711.pdf

- Duvendack, M., Palmer-Jones, R., and Vaessen, J. (2014). Meta-analysis of the impact of microcredit on women's control over household decisions: methodological issues and substantive findings. J. Dev. Effect. 6, 73-96. http://dx.doi.org/10.1080/19439342.2014.903289

- Ejaz, S., \& Farooq, M. (2019). Thematic Analysis effects of women empowerment on household decision making in Pakistan. Journal of Pakistan Vision, 20(2). Retrieved From http://pu.edu.pk/images/journal/ studies/ DFFILES/27_v20_2_19.pdf.

- Escobar. A. (1995). Encountering development: The making and unmaking of the third World. Princeton University Press, Student Ed. Retrieved From https://www.jstor.org/stable/j.ctt7rtgw

- Falk, R. F., \& Miller, N. B. (1992). A primer for soft modelling. University of Akron Press. Retrieved From https://www.scirp.org/(S(351jmbntvnsjt1 aadkposzje))/reference/ReferencesPapers.aspx?ReferenceID=1323343

- Food and Agriculture Organisation of the United Nations (FAO). (2015). Empowering Rural Women through Social Protection. United Nations. Rome, 2015. Extracted From http://www.fao.org/3/a-i4696e.pdf

- $\quad$ Fottrell, E., Azad, K., Kuddus, A., Younes, L., Shaha, S., Nahar, T., \& Pulkki-Brannstrom, A. (2013). The effect of increased coverage of participatory women's groups on neonatal mortality in Bangladesh: A cluster randomized trial. JAMA Paediatrics, 167(9), 816-825. http://dx.doi.org/10.1001/jamapediatrics.2013.2534

- Francina, P., \& Joseph, M. (2013). "Women empowerment: the psychological dimension", Rajagiri Journal of Social Development, 5(2). Retrieved From http://journals.rajagiri.edu/index.php/rssJ/article/download/154/143

- Garikipati, S., Johnson, S., Guérin, I., \& Szarfarz, A. (2016b). Microfinance and gender: issues, challenges and the road ahead. J. Dev. Stud. 53, 641-648. http://dx.doi.org/10.1080/00220388.2016.1205736

- Ginting, B., and Siregar, H. (2020). The women participation in community empowerment program to alleviate fishermen poverty in Indonesia. International Journal of Management (IJM). 11(3), 316-324. Retrieved From https://ssrn.com/abstract=3574649

- Greeley, M., \& Chaturvedi, M. (2007). Microfinance on Afghanistan: A baseline and initial impact study for MISFA. Sussex, UK: Institute of development Studies. Retrieved From https://www.researchgate.net /publication/48265077_Microfinance_in_Afghanistan_A_Baseline_and_Initial_Impact_Study_for_MISFA

- Hair, J. F., Hult, G., Ringle, C., \& Sarstedt, M. (2013). A primer on partial least squares structural equation modeling (PLS-SEM). London: Sage Publication.

- Hair, J., Ringle, C., \& Sarstedt, M. (2011). PLS-SEM: Indeed, a silver bullet. Journal of Marketing Theory and Practice, 19(2), 139-152. https://doi.org/10.2753/MTP1069-6679190202

- Hair, J., Ringle, C., \& Sarstedt, M. (2012). Editorial-Partial Least Squares: The Better Approach to Structural Equation Modeling. Long Range Planning, 45(5-6), 312-319.

- Henseler, J., Ringle, C., \& Sinkovics, R. R. (2009). The use of partial least squares path modelling in international marketing. Advances in international marketing, 20(1), 277-319. https://doi.org/10.1108/S14747979(2009)0000020014 
- International Labor Union. (2001). Human resources development, employment and globalization in the hotel, catering and tourism sector. Report for discussion at the Tripartite Meeting on the Human Resources Development, Employment and Globalization in the Hotel, Catering and Tourism Sector.

- Jayswal, D., \& Jaiswal, M. (2015). Women's Participation and Tourism Industry: An overview. Research Journal of Humanities and Social Sciences, 6(4), 269-273. Retrieved From http://rjhssonline.com/ HTMLPaper.aspx?Journal=Research+Journal+of+Humanities+and+Social+Sciences\%3BPID\%3D2015-6-4-4

- Jr Edwards, D., Mathews, D., Spear, A., \& Hartley, H. (2020). Community participation \& empowerment in marginalised contexts: Leveraging parental involvement, adult education, and community organising through social justice leadership. Journal of comparative and International education. http://doi.org/10.1080/ 03057925.20202 .1717927

- Kabeer, N. (1999). The conditions and consequences of choice: reflections on the measurement of women's empowerment, 108, 1-58. Geneva: UNRISD.

- $\quad$ Kabia, K. S. (2005). Tourism industry, Reference Press, New Delhi, p.30.

- Kala, D., \& Bagri, S. (2018). Barriers to local community participation in tourism development: Evidence from mountainous state Uttarakhand, India. Tourism, 66(3), 318 - 333. Retrieved From https://www. researchgate.net/publication/328064696_Barriers_to_local_community_participation_in_tourism_development_Evi dence_from_mountainous_state_Uttarakhand_India/link/5bb5bf3492851ca9ed37ac10/download

- Karim, R., Lindberg, L., Wamala, S., and Emmelin, M. (2017). Men's perceptions of women's participation in development initiatives in rural Bangladesh, American Journal of Men's Health, 12(2), 398-410. https://doi. org/10.1177/1557988317735394

- Kaul, N. (2002). Dynamics of tourism, Sterling publications New Delhi, 4.

- Khan, J. (2020). Women empowerment and employee gender studies background of the study. https://www.researchgate.net/publication/339439378.

- Kieffer, C. (1984). Citizen empowerment: A developmental perspective. In J. Rappaport, C. Swift, \& R. Hess (Eds.), Studies in empowerment: Steps toward understanding and action. New York, NY: Haworth.

- Kinnaird, V., \& Hall, D. (1996). Understanding tourism processes: A gender-aware framework.

- Kothari, U. (2001). Power, knowledge and social control in participatory development, in B. Cooke and U. Kothari, eds, Participation: The New Tyranny? Zed Books, London and New York, 139-152.

- Krejcie, R. V., \& Morgan, D. W. (1970). Determining sample Size for Research Activities. Educational and Psychological Measurement.

- Magigi, W., \& Ramadhani, H. (2013). Enhancing tourism industry through community participation: A strategy for poverty reduction in Zanzibar, Tanzania. Journal of Environmental Protection, 4, 1108-1122. http://dx.doi.org/10.4236/jep.2013.410127.

- Malhotra, A., Schuler, S., and Boender, C. (2002). "Measuring Women's Empowerment as a Variable in International Development", Background Paper Prepared for the World Bank Workshop on Poverty and Gender: New Perspectives.

- Maliva, N. (2016). Women's Participation in Tourism in Zanzibar. Journal of Environmental Protection, 4, 11081122. Retrieved From https://edepot.wur.nl/389702

- Mann, H. H. (2006). Empowerment in terms of Theoretical Perspectives: Exploring a Typology of the Process and Components across Disciplines. Journal of Community psychology, 23(5) 631- 656. https://doi.org/ 10.1002/jcop. 20113

- Mansuri, G., and Rao, V. (2013). Localizing Development: Does Participation Work? World Bank, Washington, DC.

- Minimol, M. C., \& Makesh, K. G. (2012). Empowering rural women in Kerala: A study on the role of self-help groups (SHGs). International Journal of Sociology and Anthropology, 4(9), 270-280. http://dx.doi.org/ 10.5897/IJSA12.003

- Mohd, I. (2016). The Roles of Tourism Industry in Socio-economic Development of Zanzibar. A case study of Zanzibar Town. PhD Thesis, Mzumbe University. Retrieved From http://scholar.mzumbe.ac.tz /handle/11192/2086

- Mosedale, S. (2014). Women's empowerment as a development goal: Taking a feminist standpoint. Journal of International Development 26: 1115-1125. https://doi.org/10.1002/jid.3050

- Moyle, T., Dollard, M., \& Biswas, S.N. (2006). Personal and economic empowerment in rural Indian women a selfhelp group approach. International Journal of rural management, 2(2):245-266. https://doi.org/10.1177/097300520600200207

- Mwamwaja, E. (2001). An Assessment of Local Community Empowerment in Ecotourism Project in Mafia. Wageningen University, Wageningen.

- Nayak, A., \& Hi, P. K. (2020). Participation in self-help groups and empowerment of women: A structural model analysis. The Journal of developing Areas; Nashville, 54(1), 19-37. http://dx.doi.org/10.1353/jda.2020.0001

- Ndaeji, M. (2014). Participation in self-help groups and empowerment among rural women in Niger state, Nigeria. PhD Thesis, Universiti Putra Malaysia. Retrieved From http://psasir.upm.edu.my/id/eprint/39588/ 
- Mustapha, N., Azman, I., \& Ibrahim, Y. (2016). Barriers to community participation in tourism development in island destination. Journal of tourism, hospitality \& Culinary Arts, 5(1). Retrieved From https://www. researchgate.net/publication/304254616_Barriers_to_Community_Participation_in_Tourism_Development_in_Islan d_Destination/link/576b333008aef2a864d20f89/download

- Palikhe, A. (2018). Women Empowerment in Tourism: Special Reference to Pokhara Metropolitan City. The Journal of Nepalese Business Studies, 11(1). https://doi.org/10.3126/jnbs.v11i1.24199

- Pambè, M. W., Thiombiano. B. G., \& Kaboré, I. (2014). Relationship between women's socioeconomic status and empowerment in Burkina Faso: A focus on participation in decision-making and experience of domestic violence. Journal of African Population Studies, 28(2), 1149-1149. https://doi.org/10.11564/28-0-563

- Peterson, N., \& Zimmerman. M. (2004). Beyond the Individual toward a Nomological Network of Organizational Empowerment. American Journal of Community Psychology, 34 (1), 129-145. https://doi.org/ 10.1023/B:AJCP.0000040151.77047.58

- Praveen, R., \& Asokan, R. (2013). Empowerment of women through tourism industry in Sikkim state, India. International journal of current Research, 5(12), 4301-4305. Retrieved From https://www.journalcra.com /article/empowerment-women-through-tourism-industry-sikkim-state-india

- Prilleltensky, I. (2012). Wellness as fairness. American journal of community psychology, 49(1), 1- 21. https://doi.org/10.1007/s10464-011-9448-8

- Rudolf, B. (2019). Freedom from violence full access to resources, Equal participation and empowerment. The relevance of CEDAW for the implementation of SDGs. Journal of Sustainable development Goals and Human Rights, 73-94. https://doi.org/10.1007/978-3-030-30469-0_5

- Saidu, M. (2014). Participation in Microfinance as a medium for empowerment among farmers community in Kano state, Nigeria. PhD Thesis, Universiti Putra Malaysia.

- Saidu, M., Asnarulkhadi, A., Ma'arof, R., \& Ahmad, N. (2014). Relationship between Socio-Economic Factors and Participation in Decision Making in Microfinance Scheme among Rural Farmers in Kano, Nigeria. Life Science Journal, 11(4), 342-347. Retrieved From http://www.lifesciencesite.com/lsj/life1104/ 047_226981ife110414_342_347.pdf

- Salim, I., \& Mwaipopo, L. (2016). Interplay between cultural endowments, promotional efforts and destination image: A case of Zanzibar as a tourist terminus. International Journal of Development Research, 6(9), 9466-9473. http://www.journalijdr.com/sites/default/files/issue-pdf/5980.pdf

- Sambangi, D. (2009). Self-help group as an effective strategy and double approach to empower women in India. Policy review, UNICEF program. Extracted from http://www.articlesbasce.com/womens-issue-articles/ selfhelpgroup-as-anempower-and-

- Sandhya, R. (2013). Recent trends in Tourism Industry and women. Indian Journal of Applied Research 3(10), 1-3. http://dx.doi.org/10.15373/2249555X/OCT2013/138

- Savithri, R. (2009). Empowerment of women through information and communication technology. PhD Thesis, IIPA.

- Scheyvens, R. (1999). Ecotourism and the empowerment of local communities. Tourism management, 20(2), 245249. https://doi.org/10.1016/S0261-5177(98)00069-7

- Scheyvens, R. (2000). Promoting women's empowerment through involvement in ecotourism: experiences from the third world. Journal of Sustainable Tourism, 8(3), 232-249. https://doi.org/10 .1080/09669580008667360

- Snyman, S. (2012). The role of tourism employment in poverty reduction and community perceptions of conservation and tourism in southern Africa. Journal of Sustainable Tourism, 20(3), 395-416. https://doi.org/10.1080/09669582.2012.657202

- Speer, P. W., \& Hughey, J. (1995). Community organizing: An ecological route to empowerment and power. American Journal of Community Psychology, 23, 729-748. Retrieved From https://link.pringer.com/ content/pdf/10.1007/BF02506989.pdf.

- Stylidis, D., Biran, A., Sit, J., \& Szivas, E. M. (2014). Residents' support for tourism development: the role of residents' place image and perceived tourism impacts. Tourism Management, 45, 260-274. 10.1016/j.tourman .2014.05.006

- Thomas, D. (2015). Moderating effects of Power distance and collectivism on empowering leadership and Psychological empowerment and self-leadership in International Development Organizations. Faculty Publications School of Business 80. Extracted From https://digitalcommons.georgefox.edu/gfsb/80

- Timothy, D. J. (1999). Participatory planning: A view of tourism in Indonesia. Annals of Tourism research, 26(2), 371-391. Retrieved From https://asu.pure.elsevier.com/en/publications/participatory-planning-a-view-of-tourism-inindonesia

- Tosun, C. (2000). Limits to community participation in the tourism development process in developing countries. Tourism management, 21(6), 613-633. https://doi.org/10.1016/S0261-5177(00)00009-1

- United Nation Commission on the Status of Women. (2002). Ttourism Management. 17(2), 96-102. 
- United Nations World Tourism Organization. (UNWTO). (2016). How can tourism contribute to sustainable development goals? Tourism and sustainable goals. Madrid: UNWTO.

- UNWTO. (2017). International year of sustainable tourism for development 2017 Kickoff, PR No. PR17007. Retrieved From https://www.unwto.org/archive/global/press-release/2017-01-19/international-year-sustainabletourism-development-2017-kicks

- Upadhyay, U., Gipson, J., Withers, M., Lewis, S., Ciaraldi, E., \& Fraser, A. (2014). Women's empowerment and fertility: A review of the literature. Soc. Sci.Med. 115, 111-120. http://dx.doi.org/10.1016/j.socscimed. 2014.06.014

- Vida, A. (2011). Empowerment of women through Participation in Women Self-help Groups in the Kumas Metropolis. Unpublished Master's thesis, University of science and Technology, Kumasi. Ghana. Retrieved From https://catalog.ihsn.org/index.php/citations/28256

- Wijesundara, C., \& Wimalaratana, W. (2016). Community participation in tourism benefits sharing schemes of Srilanka: A case of Arugam bay destination. Proceedings of ISER, 26th International Conference, Bangkok, Thailand. Retrieved From https://www.researchgate.net/publication/308266006_COMMUNITY_PARTICI PATION_IN_TOURISM_BENEFITS_SHARING_SCHEMES_OF_SRI_LANKA_A_CASE_STUDY_OF_ARUG AM_BAY_DESTINATION

- World Bank. (2019). Zanzibar: A Path to Tourism for All; Integrated Strategic Action Plan July 2019. Retrieved From http://documents.worldbank.org/curated/en/993701565250577192/Zanzibar-A-Pathway-to-Tourism-for-AllIntegrated-Strategic-Action-Plan

- World Bank. (2008). Impact of the microfinance training of trainer's course. Tokyo the Author. Retrieved From https://www.yumpu.com/en/document/view/23688740/impact-evaluation-of-the-microfinance-training-of-trainerscourse

- Wyndow, P., LI, J., \& Mattes, E. (2013). Female Empowerment as a Core Driver of Democratic Development: A Dynamic Panel Model from 1980 to 2005. World Development, 52(C), 34-54. http://dx.doi.org/ 10.1016/j.worlddev.2013.06.004

- Yadav., \& JV'n. P. (2018). A study of women participation and empowerment in software technology pack. PhD Thesis, University Jaipur (Rajastan), India. Doi or When extracted (date), From (Weblink).

- Yang, Y. (2016). Community participation for sustainable rural development: revisiting South Korean rural modernization of the 1970s. Community Development Journal, 53(1), 61-77 https://doi.org/10.1093/ cdj/bsw023.

- Yangi, Y. (2015). Saemaul Undong revisited: A case of state-society dynamics in social capital mobilisation, focusing on the role of local leaders in South Korea of the 1970s. Journal of International Development, 29(7), 9931010. https://doi.org/10.1002/jid.3048

- Ying, T., \& Zhou, Y. (2007). Community, governments and external capitals in China's rural cultural tourism: A comparative study of two adjacent villages. Tourism management, 28(1), 96-107. http://dx.doi.org/10.1016/j.tourman.2005.12.025

- Zanzibar Tourism Commission (ZCT). (2017). Statistics based on Tourism Stakeholder. Annual Report. Zanzibar. Tourism commission in Pemba. Retrieved From http://documents.worldbank.org/curated/en/ 993701565250577192/pdf/Zanzibar-A-Pathway-to-Tourism-for-All-Integrated-Strategic-Action-Plan.pdf

- Zimmerman, M. A. (1995a). The measurement of Psychological Empowerment: Issues and Strategies. American Journal of Community Psychology, 23, 581-599. http://dx.doi.org/ 10.1007/BF02506983

- Zimmerman, M. A. (1990). Toward a Theory of Learned Hopefulness: A Structural Model Analysis of Participation and Empowerment, Journal of Research in Personality, 24(1), 71-86. https://doi.org/ 10.1016/0092-6566(90)90007S

- Zimmerman, M. A., \& Rappaport, J. (1988). Citizen participation, perceived control, and psychological empowerment. American journal of community psychology, 16(5), 725-750. https://doi.org/10.1007/ BF00930023 